\title{
Mini Review: Wastewater in the Context of Punjab
}

\author{
Asima $\mathrm{Z}^{1}$ and Sumiyah $\mathrm{R}^{2}$ \\ ${ }^{1}$ School of Public Health and Zoonoses, GADVASU, India \\ 2Department of Microbiology, SKUAST, India
}

Mini Review

Volume 3 Issue 1

Received Date: December 25, 2017

Published Date: March 13, 2018

*Corresponding author: Asima Zehra, School of Public Health and Zoonoses, GADVASU, Ludhiana Punjab, India, Email: assimazehra@gmail.com

\begin{abstract}
Wastewater from the livestock farms has been the problem in India especially wastewater from dairy farms. Punjab is the leading state with respect to dairy farms and is the fast developing state but lack of the intercommunication and cooperation between the different stakeholders has complicated water pollution situation to an alarming level. Budha nallah is the well-known example of water quality deterioration in Punjab. This problem of water pollution with wastewater from livestock farms can be tackled by cooperation between the different stakeholders.
\end{abstract}

Keywords: Wastewater; Punjab; Pesticides; Insecticides; Herbicides; Labours

Abbreviations: BOD: Biological Oxygen Demand; COD: Chemical Oxygen Demand; DO: Dissolved Oxygen; WWT: Wastewater Treatment Plant.

\section{Back Drop}

Punjab, the richest state in India, is gifted with enormous natural resources and biodiversity. It is recognized for its fast developing economy with modern agricultural practices. But in recent years, land use pattern has undergone an immense change in the State. There has been an increase in the area put to nonagricultural uses such as industrial sites, housing, transport systems, recreational purposes, irrigation systems, etc. This increase in urbanization and industrialization has pushed the farmers for the intensive agricultural activity like excessive use of fertilizers, pesticides, insecticides, herbicides thereby causing pollution of both surface and groundwater. The industrial effluents discharged into the natural environment are causing water pollution. Besides, a huge amount of municipal wastes is being generated and disposed of without any treatment. $73 \%$ of the total municipal solid waste is being generated in the 5 mega towns in the State i.e, Ludhiana, Jalandhar, Amritsar, Bathinda and Patiala [1].

Water quality is deteriorated nearly at all locations in river Ghaggar followed by Satluj and Beas rivers due to the disposal of industrial, livestock and municipal wastes into them. Incidences of Gastroenteritis/water-borne diseases have been reported from a number of places like Moga, Jalandhar, Barnala, SAS Nagar due to the presence of microorganisms in water [1].

\section{Wastewater}

The pollutant can be defined as meaning "dredged spoil, solid waste, incinerator residue, sewage, garbage, sewage sludge, munitions, chemical wastes, biological materials, radioactive materials, heat, wrecked or discarded equipment, rock, sand, cellar dirt, and industrial, municipal, and agricultural waste discharged into water" as per Federal Clean Water Act. Despite this broad, sweeping definition, wastewater can typically be characterized as either domestic, industrial, agricultural 
or some combination of both, that is based on the origin of wastewater. Wastewater origin defines the characteristics of the wastewater in term of quantity and quality. Else than municipal waste, the waste from the livestock especially dairy farms is increasing rapidly in Punjab, India. The dairy industry is one of the most polluting of industries, not only in terms of the volume of effluent generated but also in terms of its characteristics as well. It generates about 0.2-10 litres of effluent per litre of processed milk with an average generation of about $2.5 \mathrm{~L}$ of wastewater per litre of the milk processed [2]. Thereby, wastewater generated in livestock farms contains highly putrescible organic constituents.

The wastewater of dairy contains large quantities of milk constituents such as casein, inorganic salts, besides detergents and sanitizers used for washing. All these components contribute largely towards their high biological oxygen demand (BOD) and chemical oxygen demand (COD) [2]. These components in effluents decompose rapidly and deplete the dissolved oxygen (DO) level of the receiving streams immediately resulting in anaerobic conditions and release of strong foul odours due to nuisance conditions. The receiving water becomes a breeding place for flies and mosquitoes carrying malaria and other dangerous diseases like dengue fever, yellow fever, chikungunya. The casein precipitation from waste which decomposes further into a highly odorous black sludge at certain dilutions the dairy waste is found to be toxic to fish also. This can be visually realized from Budha nallah in Punjab.

Not only the dairy farm wastewater is a problem, pig rearing by the low-income farmers is another factor contributing to the water pollution. As the pig rearing is increasing among the poor people in Punjab, pig manure has become another environmental pollutant. In most cases, the pig waste is drained off without any treatment and thus, contributes significantly to water pollution and environmental degradation. The solution to this problem is the wastewater treatment. An appropriate wastewater treatment or pretreatment is necessary to prevent contamination of receiving waters to levels which will interfere with their intended use. Intended water use varies from the water supply, recreation, or any other required purpose such as irrigation. Thus, wastewater treatment consists of applying a series of processes to improve its quality suitable for disposal. Usually, wastewater treatment will involve collecting the wastewater in a central isolated location, the Wastewater Treatment Plant (WWT), and then process it to an acceptable standard. Wastewater treatment can then be categorized by the nature of the treatment process operation being used such as physical, chemical or biological [3]. But in livestock farms in rural areas of Punjab, farmers use pond systems that are more desirable than continuous application systems. However, well designed and managed continuous application systems may be quite acceptable and even more suitable than pond systems in some situations. They are generally better able to protect the environment and enable farmers to make the most effective use of the nutrient and water value of the effluent [3].

But it is important to mention that as per the dairy industry owners this wastewater treatment does not give them any monetary benefit so they release it directly to nearby water streams or on land (i.e. in nature) by giving only some of the primary treatment, due to lack of awareness in this regard and lack of funds. It seems like the government is to blame but the picture was different when the workers of the dairy farms in Ludhiana were interviewed [4]. Owners were out of the country leaving some low paid labours to work for them. Labours were low in number as compared to the farm size. The labours were also unaware of the use of medicines especially antibiotics, disinfectants, clean milking, clean-in-place system and so on. It is the duty of the owner to ensure that they know what they need to know. But owners of those farms only ensure that those labours don't talk much with outsiders. Likewise, pig farmers, are reluctant to establish any pretreatment method because the cost would provide them with little economic gain. This is true indeed because small and backyard pig farm owners are financially not strong enough but awareness among the pig farmers related to the pretreatment methods can be of some help. These methods are cheap and easy to perform and after pretreatment, the farm wastewater cans the directly drained into the municipal systems. In nutshell, this situation of water pollution likes that of Budha nallah can be controlled only if all stakeholders work together. Owners from well-established farms can install their own treatment plant of required capacity. The government of Punjab can compel them to do so and can install or upgrade sewage treatments plants in different parts of Punjab. Small farm owners must be guided to follow pretreatment of wastewater. This pretreated wastewater then can be directly discharged to the municipal systems. Finally rewarding the farmers may encourage them to be more cooperative.

\section{References}

1. Water quality issues and challenges in Punjab (2014) Central Ground Water Board. Ministry of Water Resources, GOI, PP: 1-182 


\section{Open Access Journal of Veterinary Science \& Research}

2. Raghunath B, Punnagaiarasi A, Rajarajan G, Irshad A, Elango A, et al. (2016) Impact of Dairy Effluent on Environment-A Review. Integrated Waste Management in India, pp: 239-249

3. Museure TS, Hoko Z, Nhapi I (2014) Characterisation of raw sewage and performance assessment of primary settling tanks at Firle Sewage Treatment
Works, Harare, Zimbabwe. Physics and Chemistry of Earth 67: 226-235.

4. Zehra A (2017) Molecular assays targeting speciesspecific adenoviruses in different aquatic environment and its application for libraryindependent microbial source tracking (Doctoral dissertation). 